\title{
'YOUR LOVE IS LIKE BAD MEDICINE': THE MEDICAL TRADITION OF LOVESICKNESS IN THE LEGENDS OF HIPPOCRATES AND ERASISTRATUS OF CEOS
}

\author{
LFC Ribeiro (Stellenbosch University)
}

\begin{abstract}
The image of the lover physically afflicted by erōs, with erratic pulse and fiery flushes under the skin, goes back at least as far as Sappho. Ancient doctors like Galen and Oribasius of Pergamon saw the lovesick as a patient with a real disease in need of medical intervention. In Western medieval medicine, the disease had various names, such as amor heroes and erotomania. This study defines lovesickness as erotomania, a psychosomatic illness with depressive symptoms caused by unrequited love, with its roots sometimes sought in a humoral imbalance of black bile, an excess of seminal fluid or in some inflammation of the brain. It traces this tradition to the anecdotes about the physicians Hippocrates and Erasistratus of Ceos on how they diagnosed and treated royal patients suffering from lovesickness. It is argued that these stories reflect real-life medical debates. The anecdotes suggest the cause of the disease to have been seen as psychic rather than purely physiological and somatic, calling for a therapy one might term psychological. They suggest the choice treatment for a patient suffering from sick unrequited love was to requite the demands of erōs.
\end{abstract}

Keywords: Lovesickness; erotomania; erōs; Hippocrates; Erasistratus; erotic psychopathologies; melancholy.

\section{Introduction: The medical problem of lovesickness in Greco-Roman antiquity}

The image of the lover as sick beyond cure is so ubiquitous in modern pop culture, that many other songs besides Jon Bon Jovi's Bad Medicine (1988) could have served as the title for this study. The metaphor's pervasiveness attests to its longevity in Western poetry, from Sappho's green-pallored lover to Catullus' lovesick who pleads, not that his unrequited passion should respond positively to his feelings, but that his health be restored from love's 'foul sickness' (taetrum ... morbum, Catull. 76). Bon Jovi's Bad Medicine is a useful first stop in the excursion, though, and not just because of how it uses the nosological trope of lovesickness. The song also uses much the same therapeutic language on the ills of erōs that pervaded ancient Greco-Roman medicine: the plea that the ailing lover needs a cure to the disease; the symptoms that give away the sickness; the bleak prognosis that the condition is incurable. Whereas the rock ballad's nosological 
language is evidently metaphorical, ancient Mediterranean medicine took diseased erōs to be a real medical condition. Furthermore, Bon Jovi's song calls falling in love both a sickness and a medicine that the lover sorely wants but that is bad for them. Similar language can be found in the late antique Methodist physician, Caelius Aurelianus (c. $400 \mathrm{CE}$ ), who in a sternly clinical tone opposes a known therapeutic argument that love could be a 'good medicine' for obsessive mental derangement:

Some physicians hold that love is a proper remedy for madness ... they are not aware of the obvious truth that in many cases love is the very cause of it (furoris amor fuerit causa) ... surely it is absurd and wrong to recommend, of all the remedies for the disease, the very thing that you are trying to treat. $^{1}$

Greco-Roman and late antique medicine treated lovesickness as a real disease. This in itself is uncontroversial and has been demonstrated by literature across disciplines. ${ }^{2}$ We still lack a comprehensive picture of the variety of pathologies that were commonly associated in the medical and philosophical ancient archives with the desiderative emotions of erōs, epithymía, póthos and himeros. Scholarship has also so far not systematized the ancient competing explanatory models on what caused erōs to get sick and the rivalling theories on how it could be treated back to health. The present analysis cannot be a response to any plea for systematization, but focuses rather on one specific erotic disease that will be addressed interchangeably as lovesickness or erotomania, a kind of psychosomatic illness that struck patients suffering from unfulfilled affairs of the heart. This medical anthropology on erotomania will also be narrowed down to one archive: the anecdotes around the famous physicians Hippocrates of Cos and Erasistratus of Ceos that celebrate their successful diagnosis and treatment of lovesick patients. The main contribution of this study would be to show how this tradition on diseased erōs illuminates our understanding of medical and philosophical debates on the causes, diagnoses, prognoses and treatments of erotic psychopathologies in the Greco-Roman world.

Caelius Aurelianus, On acute diseases and on chronic diseases, Drabkin 1950:557-559, apud Berrios \& Kennedy 2002:384.

2 The following comprises the most recent and relevant literature: Thumiger, particularly 2018a:253-273, but also 2018b:269-284; McNamara 2016:308-327; Berrey 2014:287301; Rosen 2013:111-128; Thumiger 2013:27-40; Mazzini 2012:559-584; Caston 2006:271-298; Toohey 2004; Berrios \& Kennedy 2002:381-400; Martin 1997:201-215, Martin 1995:200-217; Gourevitch 1995:149-165; Pinault 1992:61-77; Toohey 1992:265-286; Wack 1992:3-30; Toohey 1990:143-161; Jackson 1986:352-372; Nutton 1979:194-196; Ciavolella 1976. 
Lovesickness will be defined as a condition neighbouring what later history of Western medicine called erotomania: a depressive psychological disease with significant somatic manifestations that befell patients suffering from a romantic love that was unrequited or impossible because of taboo, social stratification or gender norms. ${ }^{3}$ In one tradition under scrutiny, it was on account of the taboo love with his stepmother that the Seleucid prince Antiochus I develops symptoms of depressive melancholia and falls mysteriously ill to the point of almost dying (Val. Max. 5.7.3. ext. 1; Appian, Syr. 59-61; Plut. Demetr. 38).

According to the humoral tradition, one of the competing medical theories of Greco-Roman antiquity, depressive lovesickness was a disease concomitant with melancholia and, as such, was caused by an affluence or change in the properties hot/cold and dry/moist of the black bile humor. The theory held that a disharmony in the tetrad of body humors - blood ( $\alpha \tilde{i} \mu \alpha)$, phlegm $(\varphi \lambda \hat{\varepsilon} \gamma \mu \alpha)$, yellow bile ( $\xi \alpha v \theta \dot{\eta}$

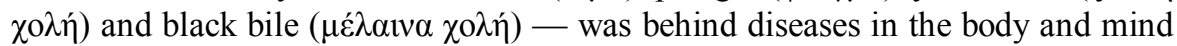
(Nat. Hom. 4). Particularly relevant to this debate is the Peripatetic Problemata ( $4^{\text {th }}$ century BCE), which sought the cause of melancholic-depressive symptoms in a change in the temperature of the black bile to too cold ([Pr.] 954a12-25) and suggested that an abundance of the humor turned patients lustful and easy targets of Aphrodite ([Pr. $]$ 953b30-35). ${ }^{4}$

Other Greco-Roman physicians would contest the humoral model of aetiology for the disease. Galen, though a doctor in dialogue with humoral medicine, rejected that lovesickness had anything to do with an imbalance of black bile, and rather saw it as psychic and emotional (Praen. 6.4-5, 7, 15; Aff. Dig., On the passions and errors of the soul, Harkins, 32). The question of the somatic aetiology of lovesickness was part of a heated debate among Platonists,

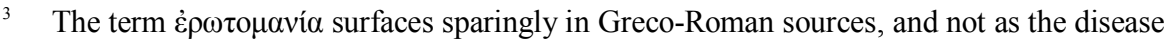
of lovesickness (Plut. De virtute morali 451E, Arius Did. Epit. Stob. 97.1). It is not the antiquity of the term, but its continued use in the sense of a 'disease of unrequited love' from medieval physicians up until the $17^{\text {th }}$ century that prompts its use in this study; see Berrios \& Kennedy 2002:383-384. Toohey 1992:265-266 also relates the ancient disease of 'unconsummated love' to the later erotomania. Toohey cites other names Western medicine has given lovesickness: amor hereos, amor heroicus, lovemelancholy, love-madness. Erotomania here is not to be confused with the homonymous disease that surfaces much later in modern psychiatry and is marked by the delusional belief that someone inaccessible has fallen in love with the lovesick; $c f$. Berrios \& Kennedy 2002:392-395.

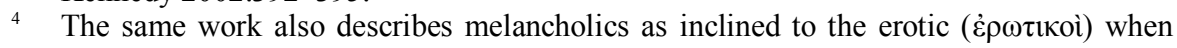
their black bile is too hot [Pr.] 954A31-32. Galen (Hipp. Epid. i-vi, CMG V 10 2, 2,

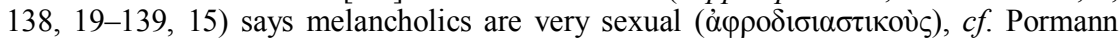
2008:F73. Rufus of Ephesus (in al-Razi, Comprehensive Book = Pormann 2008:F60) remarks melancholics have a strong desire for sexual intercourse. 
Aristotelians and physicalists on the physiological counterparts of parts of the soul, and specifically on the passion of erōs. Chrysippus in his On the soul argued, from a physicalist point of view, that the heart was the somatic constituent of the rational command center, the emotions and of eros (PHP 3 7.2-4; $37.51-52^{5}$ ). Galen in his On the doctrines of Hippocrates and Plato wants to disprove the Stoics on this point; in line with the Timaeus' metaphysics of the relationship of Plato's tripartite soul to the tissues and organs (Tim. 69D-71D), he suggests the liver as the locus of desire and of erōs (PHP $63.7 ; 6$ 8.80-82). Galen, did not, however suggest on this basis that a sickened liver was the primary cause of the disease of love-sorrow, but rather the desiderative part of the soul. ${ }^{6}$ A competing theory, which saw the material cause of lovesickness in an excess of generative seed and which capitalized on the disease's symptom of feelings of intense sexual desire, argued instead that this was a disease of the testicles. ${ }^{7}$ Yet another theory based on the physiology of soul-parts, located the passions and erōs in the brain and took erotomania to be a disease of the head. At least one of late antiquity's nosological manuals seem to follow this approach to erotomania's physiology, suggesting an alternative causation theory to the disease. Some indication of placing lovesickness in the physiology of the brain can be read from the $7^{\text {th }}$ century physician Paul of

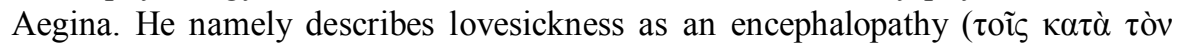

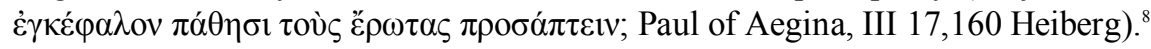

The traditions on the treatment of lovesickness attached to the legends of Hippocrates and Erasistratus seem to resist both a purely physiological explanation for the cause of the disease and the humoral-causation theory. They rather suggest erotomania to be between a psychosomatic disease and an illness of the emotions $(\pi \alpha \dot{\theta} \eta)$. Ancient physicians and philosophers were after all not unaware that emotions could cause mind and body to fall gravely ill.

Therapists of lovesickness were engaged in a debate significant to the traditions under focus: Could the lovesick be treated back to their best health?

5 In PHP 3 7.51-52, Galen quotes Chrysippus' On the soul in a passage where the Stoic engages in an exegesis of Iliad 14.315-316 to claim that the somatic locus of desire (and $e r \overline{o s})$ is in the thorax and in the heart.

6 See Rosen 2013:123-125 and De Lacy 1988:49.

7 Peter of Spain's medieval Questions on the Viaticum (ca. 1246-1272) contends with medical theories that sought a cause of lovesickness in an excess of generative seed, framing it a disease of the testicles (testiculi, in reference to both the male testicle and the female ovaries), a theory he rejects, since eunuchs were also believed to suffer from amor heroes; cf. Wack 1990:95-97.

8 For Paul of Aegina and lovesickness as an encephalopathy, $c f$. Jackson 1989:354 and

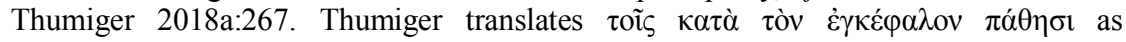
'Gehirnleiden'. 
Views on the prognosis of lovesickness varied, ${ }^{9}$ as did the therapies prescribed to patients. Treatments ranged from restoring the balance between the body's four humors, to love potions $(\varphi \hat{i} \lambda \tau \rho \alpha){ }^{10}$ to psychological-therapeutic solutions like mental exercises that would relativize the importance of love, practical advice on activities to distract one's attention away from the memory and visual-mental image of the love object, ${ }^{11}$ and satisfying erōs' demands by requiting the unconsummated love. Therapeutic coitus was sometimes prescribed, in both the medical and the philosophical traditions, as a treatment to erotomania as well as melancholy: ${ }^{12}$ some ancient physicians confused or conflated the two diseases because of their similar symptoms ${ }^{13}$ and consequently prescribed a similar set of therapies to the melancholic and the lovesick.

The legends around Hippocrates and Erasistratus of Ceos and the diagnosis and therapy of lovesickness

The following section focuses on a tradition that viewed lovesickness as serious enough to require a house-visit from the doctor. The trope can be found in ancient romance novellas such as Heliodorus' Aethiopica, but as it will be seen, developed from real-life medical debates. It was in circulation in legendary and autobiographical material of the first two centuries CE on famed physicians such as

9 A tradition relevant to the anecdotes of the physicians under scrutiny gave a prognosis to the condition as being too difficult to cure and sometimes intractable. Galen (Hipp. Epid. vi-viii, CMG V 10 2, 2, Pfaff 1956:494-495) remarks that the condition may become inveterate and very difficult to cure. The Vandal North African poetic reworking of Soranus' legendary account of Hippocrates' healing of King Perdiccas, the Aegritudo Perdicae ( $5^{\text {th }}$ century CE), not only assesses the disease as intractable, but also beyond the powers of rational medicine. See Thumiger 2018a:269 on the Aegritudo Perdicae. Thumiger reads the Ae.P. to argue rational medicine cannot treat lovesickness, this being exemplified in Hippocrates' giving up on his patient. See also Mazzini 2012:559-584.

10 This study cannot cover the therapeutic solution to lovesickness from love magic. Love potions $(\varphi i ́ \lambda \tau \rho \alpha)$ and other love spells did not target the lovesick patient, but aimed at turning the person who was the source of the unrequited love as maddened with erōs as the obsessed lover. See Faraone 1999 and McNamara 2016:311.

11 Thumiger 2018a:253-273 is particularly rich in mapping how ancient therapists with either a philosophical or medical training were concerned with the role the sense of sight and the visual memory of the beloved had in the transmission of lovesickness.

12 Among the physicians in antiquity, see Rufus of Ephesus, Aretaeus of Cappadocia and Oribasius. For the philosophers, see Lucr. Rer. Nat. 4.1065-1072.

13 The literature consulted for the article on melancholy is: Jouanna 2012:229-258; Pormann 2008; Van der Eijk 2008:159-178 and Van der Eijk 1990:33-72; Toohey 1992:265-286 and Toohey 1990:143-161; Jackson 1989, and Klibansky et al 1979. 
Hippocrates, Erasistratus and Galen. ${ }^{14}$ The stories are found dispersed in various genres, history and natural history, romance and medical writing. Though this study focuses on anecdotal material, it will be argued that it preserves medical debates on the diagnosis, prognosis and therapy of erotomania.

As the basic plot goes, a doctor pays a visit to a patient with symptoms of despondency. The depressive ailment defies diagnosis and treatment. In at least one version, the doctor suspects at first that the patient's depressive symptoms point to a case of humoral melancholy (Galen Praen. 6.4). Either by his astounding skills or by chance, the doctor finds out that the patient is ill not on account of some malady of the body, but suffers from a psychosomatic ailment caused by the patient's emotions $(\pi \alpha \dot{\theta} \eta)$. The patient is diagnosed with the disease of 'unconsummated love' (erotomania). The incident illustrates and celebrates the physician's skill for solving the diagnostic mystery.

Hippocrates is arguably the oldest ${ }^{15}$ of the famed doctors celebrated for correctly diagnosing a patient wasting away from lovesickness. In an anecdote recorded in Soranus of Ephesus' Life of Hippocrates, the doctor diagnoses and heals the unrequited love of the Macedonian king Perdiccas II (450-413 BCE) for his father's concubine:

He treated all Greece and was so admired that he was summoned by Perdiccas, king of the Macedonians, who was thought to be consumptive, to come to him at public expense with Euryphon, who was slightly older than he. Hippocrates interpreted by certain signs that the affliction was psychic in origin. For after the death of Alexander, his father, Perdiccas fell in love with his mistress Phila. Hippocrates explained the situation to her after he caught Perdiccas changing colour when he looked at her. He freed him from his illness and revived him. ${ }^{16}$

14 On the topos of famed physicians treating lovesick patients, see the excellent analysis of Pinault 1992:61-77. Like this study, Pinault believes these anecdotes represent an ongoing and real medical debate. On the trope see also Zadorojnyi 1999:515-532; Mesulan \& Perry 1972:546-551; Amundsen 1974:328-337; Ciavolella 1976:23-27; Nutton 1979:194-196. More recently, Robiano 2003:129-149 treats the trope of diagnosis of lovesickness in Heliodorus Aethiopica.

15 It is hard to establish historical fact from imagination when it comes to the life of Hippocrates of Cos, who is believed to have lived throughout the second half of the $5^{\text {th }}$ century BCE.

16 Life of Hippocrates according to Soranus (VHSS). Translation is from Pinault 1992:6.

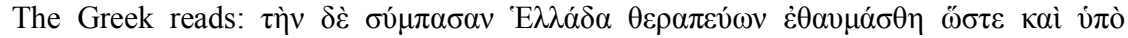

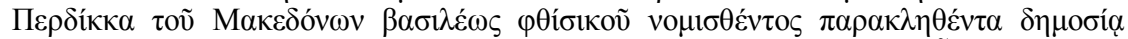

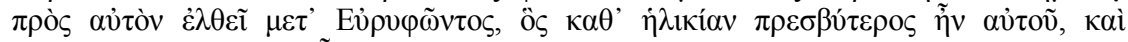

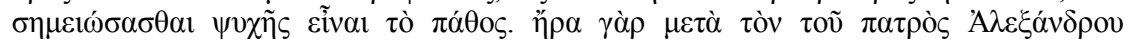


Though versions of the anecdote on the lovesick king Perdiccas II appear in Lucian (Hist. conscr. 35) and Galen (Opt. Med. 3), Soranus alone names Hippocrates as the court physician. The story has long been considered fictitious ${ }^{17}$ on the grounds that the physician Euryphon, from the rival medical school of Cnidos $\left(c .5^{\text {th }}\right.$ century BCE), appears associated with Hippocrates. Euryphon was according to medical doxography a pioneer specialist on female infertility. Apart from this mention, no other reference to Euryphon's expertise in the treatment of lovesickness is found anywhere. ${ }^{18}$

It has been suggested that the story as preserved in Soranus derives from a similar but earlier tradition on the doctor Erasistratus of Ceos. ${ }^{19}$ Further inconsistencies point to its derivative nature. For instance, the legend in Soranus considers it problematic that Perdiccas II has fallen in love with his father's concubine Phila, even though Alexander I (first half of $5^{\text {th }}$ century BCE) is already dead. In the Erasistratus story, the Hellenistic prince Antiochus' lovesickness for his father's wife is taboo because the king is still alive and married to the object of the prince's love. In the context of Soranus' VHSS, Perdiccas' forbidden love for his father's mistress makes less sense.

Relevant to this study's focus on the medical debates surrounding erotomania, is the story's depiction of the symptoms that disclose the lovesickness of the patient. King Perdiccas changes colour as he gazes at his father's mistress. This is a known ancient trope on the symptoms of lovesickness reaching as far back as the lyrical presentation in Sappho fr. 31. The anecdote in Soranus also attempts to explain the aetiology of Perdiccas' erotomania: even though he is

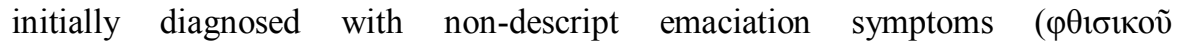

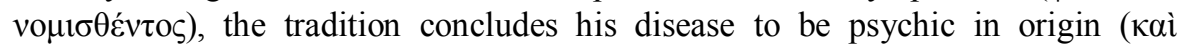

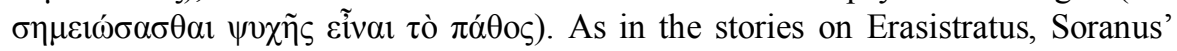

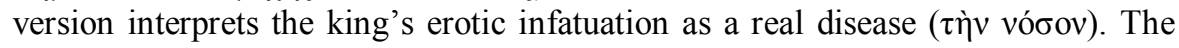
description of outward signs and the question of where the illness originated (psyche or body) both reflect the medical debates on erotomania current at the time.

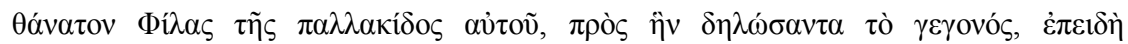

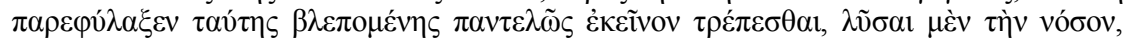

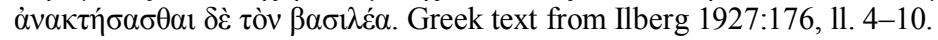

17 On the unhistorical nature of the anecdote, see scholarship in Pinault 1992:61, n. 4.

18 On Euryphon of Cnidos as a pioneer on obstetrics, see Soranus, Gyn. 1.35, 4.36 (Temkin 1991:33 and 203). On the pioneering role of Euryphon and the Cnidian school on ancient obstetrics see Tsoucalas et al. 2014:369 and Nutton 2006.

19 I follow here Pinault's convincing observations (1992:70-77) that the inconsistent nature of the anecdote on Hippocrates points to it being secondary to the Erasistratus story. 
The Hellenistic physician Erasistratus of Ceos was credited to have discovered the body's nerve system together with his contemporary from the Alexandrian school of medicine, Herophilus of Chalcedon. ${ }^{20}$ He was also known for disseminating the principal tenet of the Physicalist soul doctrine: that the soul was corporeal, since imbued everywhere in the body. ${ }^{21}$ The Physicalist soul-theory accorded well with the view that certain diseases, like lovesickness, were psychosomatic.

The importance of Erasistratus in the medical history of lovesickness is reflected in an anecdote relating how he once treated a Seleucid royal patient ailing from pathological love. The story was widely circulated from the early first century $\mathrm{CE}$ into late antiquity, with the earliest full account in Valerius Maximus' Facta et dicta memorabilia (Val. Max. 5.7.3. ext. 1). The plot is later alluded to in Pliny (HN 29.5) and reproduced at length by Plutarch (Demetr. 38), Appian (Syr. 59-61) and Lucian (Syr. D. 17-18). ${ }^{22}$ Galen, On prognosis (Praen. 6, ca. $178 \mathrm{CE}$ ) acknowledges the tale and cites Erasistratus' feat of diagnosis in order to boast over his own medical career. ${ }^{23}$ The story resurfaces in Julian (Mis. 347) and is summarized centuries later in the Suda (s.v. 'Erasistratus'). ${ }^{24}$ Though only Galen's Praen. 6 can be classified as a medical case story ${ }^{25}$ and as such belonging to the Greco-Roman rational medicine archive, I would argue that the Erasistratus

20 Nutton 2013:13-14, 135-36. Both are supposed to have lived $c a .330 / 20-260 / 50$ BCE. Nutton notes with reservation that past scholarship placed Erasistratus' practice in Ptolemaic Alexandria and suggests caution on reconstructing the life of the physician, p. 135. Fraser 1969:533-536 locates his medical practice instead in Antioch on the evidence from our anecdotes in which he is the court physician of Seleucus I Nicator (Appian, Syr. 59; Plut., Demetr. 38). It is unlikely that Erasistratus would have been able to advance his discoveries on the nerve system and valves of the heart without conducting dissections in humans, and Alexandria is recorded as the center where the scientific Renaissance on human anatomy based on this procedure was carried out. Celsus, De Medicina (Proem. 23-24) has both Herophilus and Erasistratus performing vivisections in prisoners of war in Alexandria. On these points, see Lloyd 1975:172175.

$21 \quad$ See Von Staden 2000:93-95, 102.

22 An allusion to both stories of the healing of Perdiccas II and Antiochus I appears in Lucian, Hist. conscr. 35. But neither Hippocrates nor Erasistratus are credited with the healing of the lovesick patients.

23 Nutton 1979:49, 100-105.

24 See treatment of the sources of the story and its history of transmission in Pinault 1992:63; Nutton 1979:194-196 and Amundsen 1974:333-334.

25 Nutton 1979:59-60 and Lloyd 2009:126 argue that On prognosis should be read as sharing in the genres of the medical case story, the medical autobiography and an apology of Galen's practice. 
anecdote transmitted by Valerius, Appian and Plutarch preserves medical debates on the diagnosis, prognosis and treatment of lovesickness. ${ }^{26}$

As the story goes, the doctor Erasistratus of Ceos is summoned by Seleucus I Nicator, founder of the Seleucid dynasty, to care for the abated health of his son, Antiochus I. Seleucus I ruled from $c a$. 312-281 BCE, as co-regent with Antiochus I Soter from $c a$. 292/3-281 BCE after marrying his son to his own second wife Stratonice, daughter of Macedonian king Demetrius Poliorcetes. ${ }^{27}$ The tale of how Erasistratus is called by Seleucus to examine a bedridden Antiochus is contextualized just before the start of the co-regency. Some versions of the story serve to explain why Seleucus I came to offer his own wife as spouse to his son. Whether the tale contains some historical basis has been the subject of debate. No matter how vivid the plot details of Erasistratus' visit, ${ }^{28}$ it is problematic that the tradition is not unanimous in naming him as the doctor who treats Antiochus I. Valerius Maximus is uncertain whether it had been Erasistratus or a certain astrologer Leptines who treated the royal (Val. Max. 5.7.3. ext. 1). According to Garofalo (1988:20), more problematic is that Pliny alludes to a competing version of the story ( $H N$ 7.123) that credits Cleombrotus, physician and father of Erasistratus, ${ }^{29}$ with healing Antiochus I of lovesickness. Garofalo considers it more plausible that the tale originally credited the less known Cleombrotus with the healing and that later transmission attached the cure to the more illustrious career of Erasistratus. Scholarship has therefore settled on the view established long ago by Wellmann that the tale is anecdotal and develops the popular motif celebrating the career of famed doctors in their ability to diagnose patients sick with love. ${ }^{30}$

26 The case for taking the Erasistratus-Antiochus anecdotal material to have engaged scientific-medical debates on lovesickness has been made by Pinault 1992:61-77. An important contribution of the present study is to demonstrate how that is indeed the case, even if the Erasistratus cycle does not offer a rational medical study of the disease such as one sees, for example, in the longer therapeutic discussion of love-sorrow in Galen Hipp. Epid. vi-viii, CMG V 10 2,2, 494-495. See Robiano 2003:132, 133, 147 for the argument that the science and medicine on lovesickness in Heliodorus' Aethiopica should be taken seriously.

27 Demetrius Poliorcetes is said to have entered into an alliance with Seleucus I by marrying his daughter to the Seleucid king circa 299/8 BCE.

28 So Fraser 1969:533: 'This is told in detail by Valerius Maximus, Plutarch and Appian with such a mass of circumstantial detail that it is difficult either to reject it completely or to regard it as embodying a major chronological error'.

29 Little to nothing is known about the physician Cleombrotus. We read that he was the

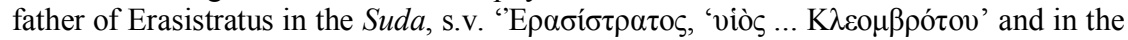
list of ancient physicians at the Codex Laur. 73.1 (folio 143r) of Celsus, 'Erasistratus Cleombroti Filius Ceius', $c f$. Garofalo 1988:59, fr. 1A and 1B and Wellmann 1900:370.

30 Wellmann 1900:371ff, esp. 379-382; Wellmann 1907:333-350; Wellmann 1930:322ff., esp. 327-328. Amundsen 1974:334, following Wellmann 1900, thinks the chronology of 
The treatment of lovesickness was apparently an important accomplishment in an ancient doctor's professional résumé. For the present purposes it matters less whether the story passes on reliable memory on the career of Erasistratus, but rather that it represents a serious scientific-medical trope; that is, that already in the early $1^{\text {st }}$ century CE it was not considered absurd that a doctor should pay a visit to a patient suffering from symptoms of lovesickness. ${ }^{31}$

What follows is a summary of the story's motifs found in the various versions of Valerius Maximus, Plutarch and Appian. ${ }^{32}$ In some strata of the story, Antiochus I is bedridden and close to dying (Val. Max. 5.7.3. ext. 1). Though this is not explicitly said by Valerius, other parts of the tradition attribute the patient's dire condition to be self-caused. Self-harm was after all a symptom of melancholic lovesickness and humoral melancholia ([Pr.] 954b35; Aretaeus, On Chronic Diseases 1.5). Appian remarks that the youth 'gave in' and was 'cooperating to die' (Syr. 59). In a longer commentary, Plutarch (Demetr. 38) describes how the prince was killing himself by 'loosening care' ( $\pi \alpha \rho \alpha \lambda v ́ \varepsilon ı v \theta \varepsilon \rho \alpha \pi \varepsilon i ́ \alpha \varsigma)$ and negligence $(\dot{\alpha} \mu \varepsilon \lambda \varepsilon i \underline{\alpha})$ of his body through voluntary starvation $(\tau \rho \circ \varphi \tilde{\eta} \varsigma \dot{\alpha} \pi \circ \chi \tilde{\eta})$.

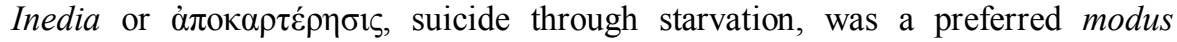
moriendi of the lovesick..$^{33}$ All extant versions of the tradition describe the prince as displaying psychological signs of drooping, torpor and depression, symptoms the medical tradition also ascribe to humoral melancholia.

The story concludes that Antiochus' disease did not originate in his body, but in his mind/soul. Part of the material also seems to be disputing the theory that a humoral imbalance of the black bile could be the cause of his lovesickness. Rather, the prince's sickness is defined as erotomania, interpreted as a psychic disease caused by an impossible love (Plut. Demetr. 38, Appian Syr. 59).

having Erasistratus as court physician to Seleucus I in 293/2 BCE is problematic, since he would have been too young for the post and thinks his father Cleombrotus was most likely the physician who tended Antiochus I. Pinault 1992:66 raises suspicion about the authenticity of the visit since versions of the tale cannot agree on who was the physician of Antiochus I. More recently Nutton 2013:136 follows Garofalo 1988:20 in claiming the name of Erasistratus was attached to the story at a later stage.

31 See Galen Praen. 6 for an autobiographical account of such a visit. I see no reason to agree with Pinault 1992:62 that one has to wait until the development of the motif in the Greco-Roman novella to arrive at physicians being called to treat the lovesick.

32 These versions represent the earlier transmission stage of the anecdote. Breebaart 1967:157-158 rightly supposes a common source for Plutarch and Appian, whose highly conjectural identity was perhaps the $3^{\text {rd }}$ century BCE Greek historian Phylarchus. Valerius Maximus appears to have had access to an independent version of the tale.

33 See Toohey 1992:280-281 for a discussion of the lovesick attempting self-harm through starvation (inedia) in the examples of Phaedra in Euripides and in the romance novel tradition. 
Antiochus I suffers for his taboo passion in secret and, by refusing to pursue his feelings for his father's wife, sees his symptoms become more severe. After a series of visits and through observing the signs of the 'psychosomatic' disease, ${ }^{34}$ the physician conjectures the nature of the illness. A sure diagnosis is reached after Erasistratus puts the prince through an empirical test: whether his symptoms would manifest in the presence of men and women of the court other than Stratonice.

In most versions of the anecdote the experiment amounts to monitoring the patient's irregular pulse, but also his heavy breathing and changes in facial colour. Later attention to the Erasistratus' medical examination narrowed it down to sphygmology, the measurement of the patient's pulse through the palpation of the wrist, as the test that establishes the diagnosis (Val. Max. 5.7.3. ext. 1; Plut. Demetr. 38; Galen Praen. 6; Lucian Syr. D. 17; Suda 'Erasistratus'). The reason for that appears to have lied in a growing medical consensus, headed by the likes of Galen and Marcellinus (late first to second century CE), that saw the beating of a patient's heart as a special tool for the prognosis and diagnosis of a variety of illnesses, instead of the stool or the urine as in Hippocratic medicine. The pulse was also sometimes seen as the hermeneutic key to patients' undisclosed secrets they would hide from the doctor. According to Marcellinus' popular manual on the subject, monitoring the pulse (sphygmology) empowered the physician with insight into hidden things ( that a violent and irregular pulse could indicate lovesickness was later called pulsus amatorius, but could arguably have been common medical currency already at the start of the Common Era. The Erasistratus-Antiochus stories rely not so much on this exact dogma, but rather on the idea that the patient's pulse could reveal to the doctor who the object of the patient's lovesickness was. ${ }^{35}$ With Antiochus, Stratonice alone leaves him with a wild pulse, which indicates the proper treatment to the physician: to requite the patient's erōs for the queen. Requiting lovesickness was, as we have seen, a medical therapy for the malady. The anecdote reaches the surprising happy ending of the prince's recovery from his otherwise incurable illness when Erasistratus first dupes the king to think that the patient is in love with the doctor's own wife, then guides Seleucus to declare he would be willing to offer

34 Mesulan \& Perry 1972:546-551.

35 On sphygmology as a form of prognosis, $c f$. Galen De diff. puls. 1.1. Horine 1941:209249 is still a useful study on the pulsus amatorius. On Marcellinus and the pulse examination as conveying 'hidden things of the heart', Puls. 18-19: ' $\theta i \xi \xi \varsigma \delta \grave{\varepsilon}$

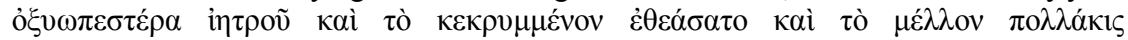
$\dot{\varepsilon} \mu \alpha v \tau \varepsilon v ́ \sigma \alpha \tau o$ '. Lewis 2016:353 discusses the view that pulse measuring revealed things the patient wanted to keep hidden from the doctor. On the pulsus amatorius as vehicle of disclosure of who the patient was in love with, see Horine 1941:214-215, 223-225 and Wack 1992:136. 
his own Stratonice for his son's cure should she have been the object of the prince's affection. The doctor finally reveals Stratonice to be indeed the panacea to Antiochus' condition.

From a summary of the motifs, this study now proceeds to Appian's version of the anecdote in order to establish what it may disclose of medical debates on erotomania in the first centuries of the Common Era. Syr. 59 employs medical terminology and displays an interest in the diagnostic controversy of melancholic lovesickness that concerned the ancient medical therapists:

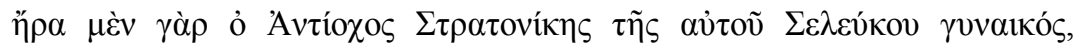

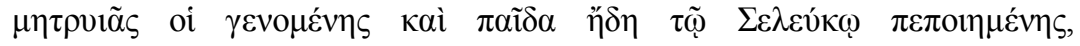

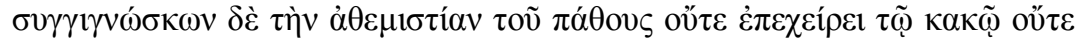

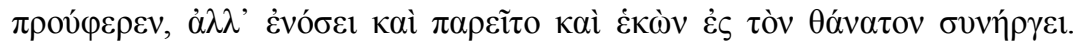

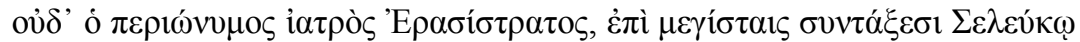

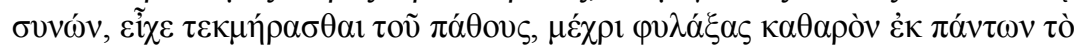

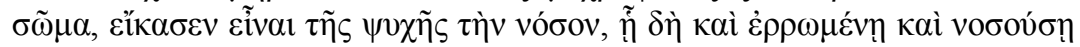

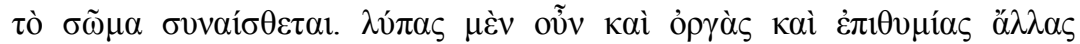

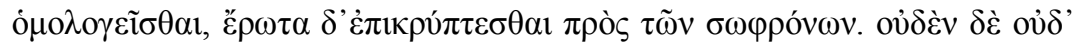

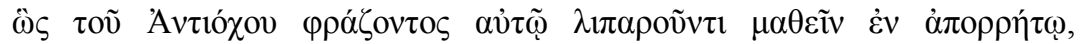

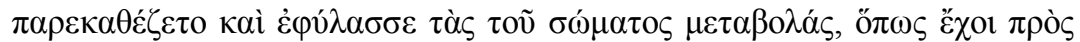

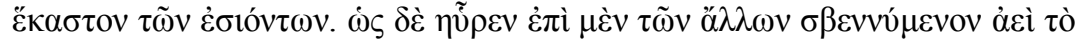

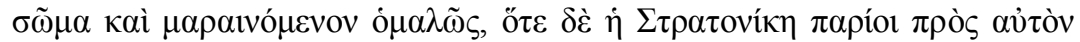

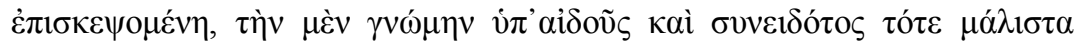

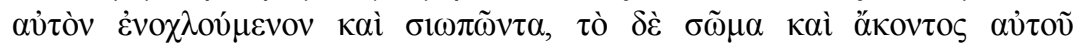

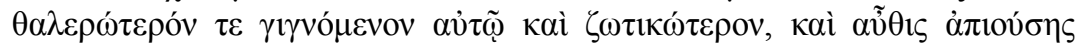

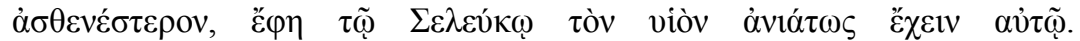

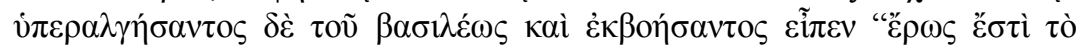

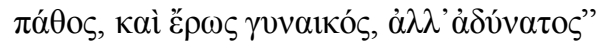

Antiochus was in love with Stratonice, the wife of Seleucus, his own stepmother, who had already borne a child to Seleucus. Recognizing the impropriety of his feelings, Antiochus did nothing wrong, nor did he manifest them, but he fell sick, gave up, and willingly cooperated to die. Nor could the celebrated physician, Erasistratus, who was serving Seleucus at a very high salary, arrive at a diagnosis and best course of action for his disease. At length, observing that his body was clear of the symptoms, he conjectured that the disease was of the soul, with which, being healthy or diseased, the body shares the sentiments, ${ }^{36}$ and he knew that, while grief,

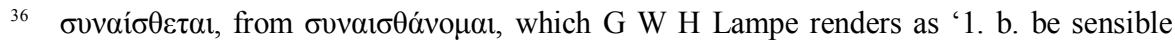
along with ... 2. b. share the sentiments of, be of the same mind'. A freer rendition of 
anger, and other desires coming from the self-restraint are confessed, erōs is nevertheless concealed. And even then Antiochus would confess nothing when the physician asked him earnestly and in confidence, he took a seat by his side and watched the changes of his body to see how he was affected by each person who entered his room. He found that when others came, his body was all the time wasting away and waning at a uniform pace, but when Stratonice came to visit him his mind was greatly troubled because of modesty and conscience, and he would be silent. But his body, now involuntarily, would turn more youthful and full of life, and when she went away it would turn weaker again. So the physician told Seleucus that his son had an incurable disease. The king was overwhelmed with grief and cried aloud. Then the physician added, 'His disease is love, love for a woman, but a hopeless love'. ${ }^{37}$

Though Appian's Syr. 59 is not strictu sensu a medical case story, unequivocal scientific jargon on diagnosis and prognosis is employed in the narrative. Before Appian has Erasistratus triumph over Antiochus' mystifying illness, the anecdote relates that the doctor could not 'form a judgment on the disease based on the

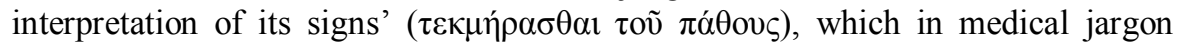
meant, to offer both a diagnosis and the course of treatment of an infirmity. ${ }^{38}$ Erasistratus' diagnostic uncertainty in the story is justified, since Antiochus' lovesickness shared many symptoms with humoral melancholia. A misdiagnosis of the two was a concern shared by physicians such as Galen and Aretaeus of Cappadocia.

Appian is in no doubt Antiochus' suffering from unrequited love comes from an actual disease. Pathological language is used throughout to describe the

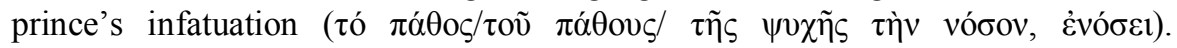
Erasistratus' concluding remarks at Syr. 59 even seem to indicate a more precise

the passage could read, with which [the body] is healthy or diseased, since the body is in accord and shares the sentiments [of the soul]. The freer rendition of the passage reads

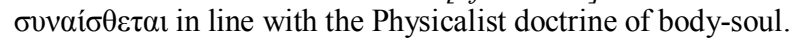

37 Appian, Syr. 59. Translation is based on White 1912:218-219 with indication of changes in italics.

38 Syr. 59. On $\tau \varepsilon \kappa \mu \alpha i ́ p o \mu \alpha 1$, LSJ observes that after Homer the verb substantially means, 'to judge from signs and tokens, to estimate ... to form a judgment or conjecture.' A search of the lemma leads to 177 occurrences in Galen and 45 occurrences in the Hippocratic Corpus. A closer look at the Hippocratics' use of the $\tau \varepsilon \kappa \mu \alpha i ́ p o \mu \alpha \iota$ evinces the lemma becomes common in medical jargon, for instance, in the sense of 'offering a prognosis' ( $\varepsilon \varepsilon \kappa \mu \alpha i ́ \rho \varepsilon \sigma \theta \alpha)$ for patients with chronic fever, Hipp. Prog. 24.70-74. See also $\tau \varepsilon \kappa \mu \alpha i ́ p \varepsilon \sigma \theta \alpha \mathrm{l}$ in the sense of 'judging' the best treatment of baths (Hipp. Acut. 68) and as 'judging the signs' of stool to indicate the best course of medical action (Hipp. Aph. 1.23). 


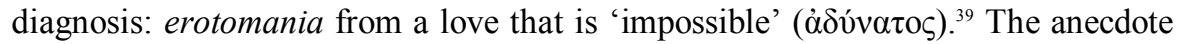
seems also aware of the tradition on lovesickness leading to self-harm. Is the note in Syr. 59 saying Antiochus had 'given up' ( $\pi \alpha \rho \varepsilon i \tau o)$ and was 'cooperating' (бטvท́ $\rho \gamma \varepsilon 1$ ) to die a nod that he was starving himself to death? The many references to the prince's wasting body could indicate that.

In Appian, the royal patient shows signs of depressive melancholia when he is not in the presence of his love-object — his body goes out like a fire ( $\left.\sigma \beta \varepsilon v v{ }^{\prime} \mu \varepsilon v o v\right)$ and is wasted ( $\left.\mu \alpha \rho \alpha v o ́ \mu \varepsilon v o v\right)$. But as he sees Stratonice, his body

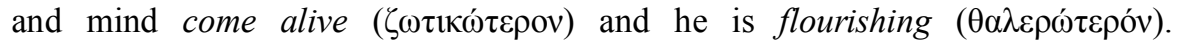
The oscillation of the prince's symptoms between excitability and torpor reminds one of the Peripatetic treatment of melancholia in the Problemata. Problemata 30.1 presents a theory that had some traction in later medical debate, that a disharmony in the black bile's temperature toward too cold or too hot lead to anomalous symptoms. Too cold black bile turns a person despondent ( $\dot{\alpha} \theta v \mu i ́ \alpha \varsigma)$ and

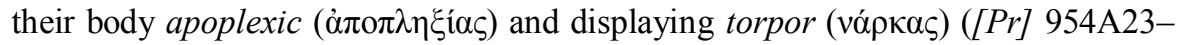

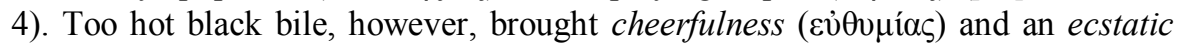

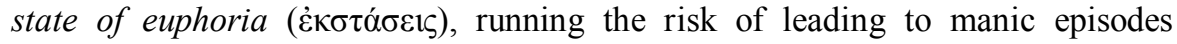
([Pr]954A25). Appian's source may have considered a melancholic humoral origin for the royal patient's lovesickness, but in the end does not attribute the disease to an imbalance in the black bile. The prince's body 'is untouched' by any condition

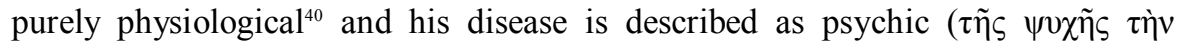
vóбov). Syr. 59-61 then goes on to offer an alternative explanation for how the psychic and the somatic are intertwined so that the prince's body would manifest the pathology of the soul. The language used is reminiscent of Chrysippus' Physicalist psyche dogma, even if the explanation given seems incomplete from an ancient scientific perspective on soul-body theories. Antiochus' somatic symptoms of lovesickness are born out of the intrinsic kinship between body and soul. As in Stoic Physicalism, because the soul is dispersed in the body, both are said to 'share the sentiments of each other' ( $\sigma v v \alpha i \sigma \theta \varepsilon \tau \alpha)$, one following the other in health and sickness. $^{41}$

Appian or the source used by him on the Erasistratus-Antiochus anecdote, seems privy to medical debates on erotomania from the beginning of the Common

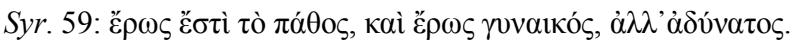

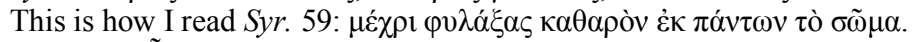

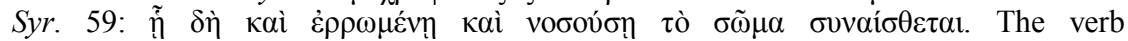
$\sigma v v \alpha 1 \sigma \theta \alpha \dot{v} 0 \mu \alpha 1$, to 'share the same mind', is used in Chrysippus on how the heart

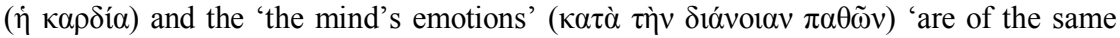

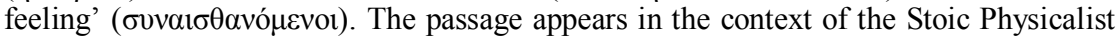
claim that the part of the soul responsible for the soul's emotions and reason is in the viscera of the heart, $c f$. Galen PHP 2 7.7-10. See also PHP 3 1.25. 
Era. These discussions hinged on the challenges of diagnosing lovesickness and naming the causation of its psychosomatic symptoms in the soul-body conundrum. It describes the prince's alternating manifestations of despondency and euphoria as signs that give away the diagnosis of the royal's troubles. It concludes that the prince is suffering from depressive erotomania, which it understands to be a

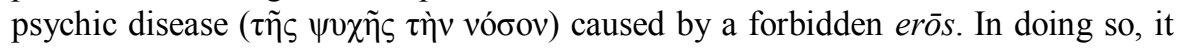
refutes a purely physiological etiology, likely also rejecting a humoral imbalance explanation for the condition. Because it believes the soul imbued in the body, the prince's psychic disease is readily spotted in the surface of his physiology.

The Erasistratus anecdote also found its way into Plutarch's Lives where it similarly alludes to medical debates on erotomania. ${ }^{42}$ The moral philosopher narrates the story in his Life of Demetrius 38 in the context of the Syrian wars. The story's primary aim is to explain how Antiochus found himself married to his own stepmother circa the start of his co-regency with his father Seleucus I Nicator:

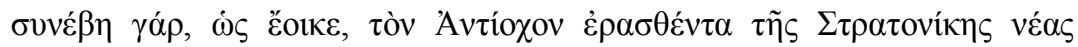

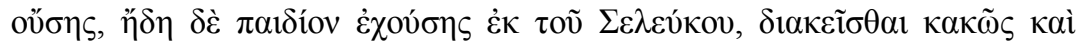

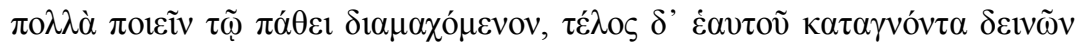

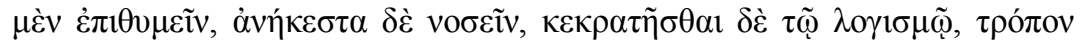

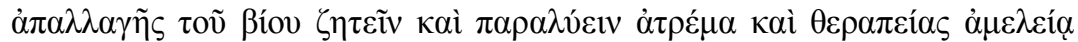

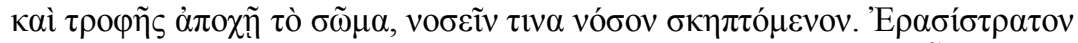

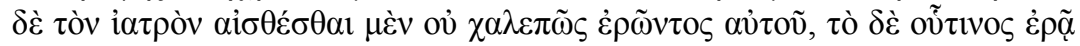

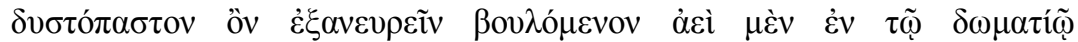

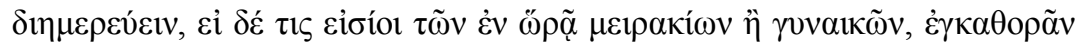

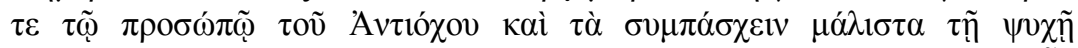

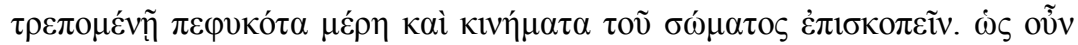

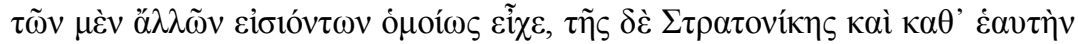

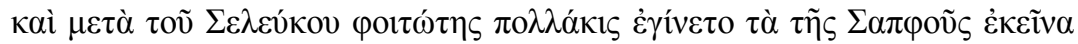

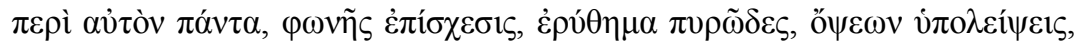

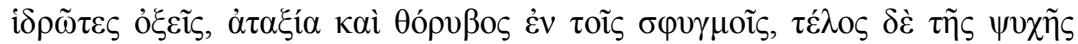

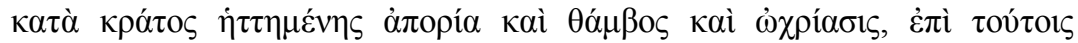

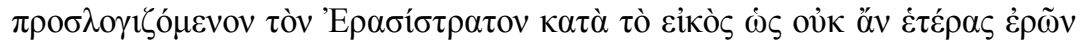

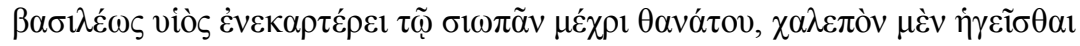

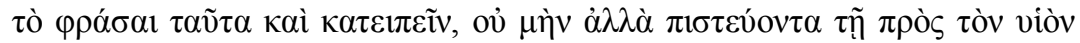

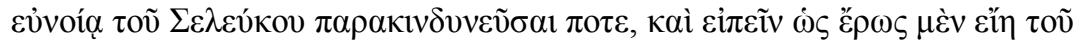

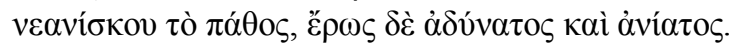

42 Thumiger 2018a:265 is also of the opinion that Plutarch is a competent interlocutor of ancient medical discourse; see also Durling 1995:311-314. 
For it came to pass, as it would seem, that Antiochus fell in love with Stratonice, who was young, and was already mother of a little boy by Seleucus. Antiochus was distressed, and resorted to many means of fighting down his passion, but at last, condemning himself for his inordinate desires, for his incurable disease, and for the subjugation of his reason, he determined to seek a way of escape from life, and to slowly destroy himself by loosening care of the body and through negligence to feeding himself, by affecting some disease. But Erasistratus, his physician, perceived quite easily that he was in love, and wishing to discover who was the object of his passion (a matter not so easy to decide), he would spend day after day in the young man's chamber, and if any of the beauties of the court came in, male or female, he would study the countenance of Antiochus, and keep watch for parts and movements of the body which are most prone by nature to sympathize and suffer together with the alterations in the soul. Accordingly, when anyone else came in, Antiochus showed no change; but whenever Stratonice came to see him, as she often did, either alone, or with Seleucus, lo, those tell-tale signs of which Sappho sings were all there in him, stammering speech, fiery flushes, darkened vision, sudden sweats, irregular palpitations of the heart, and finally, as his soul was taken by storm, helplessness, stupor, and pallor. And besides all this, Erasistratus reasoned further that in all probability the king's son, had he loved any other woman, would not have persisted to the death in refusing to speak about it. He thought it a difficult matter to explain the case fully to Seleucus, but nevertheless, relying on the father's kindly feelings towards his son, he took the risk one day, and told him that love was the young man's disease, a hopeless love that could not be cured. ${ }^{43}$

Whether or not historians have reason to believe the anecdote originally praised the physician Erasistratus for his genius of medical diagnosis, the primary role the story plays in Plutarch is to eulogize the abnegated love of Seleucus for his son. Plutarch even goes as far as having Erasistratus address king Seleucus as the true physician of his son's illness, since it is the father who 'heals' the prince of his lovesickness by allowing him to take Stratonice as his wife: the physician 'clasped him by the hand and told him he had no need of Erasistratus; for as father, husband, and king, he was himself also at the same time the best physician of his household'. ${ }^{4}$

43 Translation is modified from Perrin 1959.

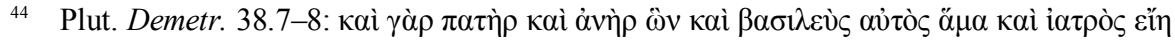

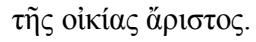


Plutarch's claim that Seleucus was the true physician of Antiochus also carries medical considerations about the story's choice of treatment for the lovesick. So is the note, in Appian as well, that the prognosis of the youth's sick

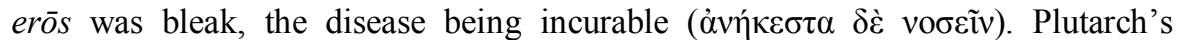
Erasistratus diagnoses the prince's disease as a case of intractable erotomania, due to a love of an impossible kind. ${ }^{45}$

Here I want to suggest Plutarch thinks Antiochus is suffering on account of

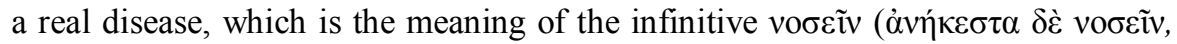
Demetr. 38.2). The gloss following Demetr. 38.2 that the prince was slackening his body and neglecting to eat 'by affecting some disease' ${ }^{46}$ should not be read as a blanket statement on erotomania not being a real disease. It is clear from Plutarch's agreement with the basic medical elements of the story that he is not disputing that some forms of intense erōs can, as a matter of fact, make one sick. He even acquiesces erōs may sicken a person to the point of them displaying a series of psychosomatic symptoms regarded as classic signs of lovesickness, including the lover's erratic heart pulse (pulsus amatorius). Plutarch likewise does not dispute that it is proper for the office of the physician (Erasistratus) to diagnose and treat a patient suffering symptoms of love-sorrow. A possible interpretation of the gloss in Demetr. 38.2 would be that, though Plutarch believes erōs can develop into a sickened condition of the soul affecting the body, he still resisted calling it a nosos. This interpretation fails to explain, however, why he did not find issue in addressing the prince just some lines before as suffering from an 'incurable disease

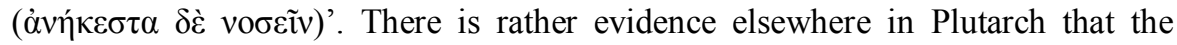
philosopher joined the debate that diagnosed certain shades of passionate erōs as a disease (nosos). In Amatorius 755E, as the dialogue defends the honour of the widow Ismenadora claiming she had not abducted the youth Bacchon so as to marry him on account of wickedness, but because of an irresistible infatuation borne out of divine possession that clouded her sense of reason, ${ }^{47}$ Ismenadora's erotic condition is compared to that of someone struck with epilepsy, a disease of the body also thought to originate from divine possession ( $\alpha \mu \varepsilon \dot{\lambda} \varepsilon \varepsilon 1 \kappa \alpha i ̀ ~ \sigma \omega ́ \mu \alpha \tau o ́ \varsigma \tau \iota \zeta$,

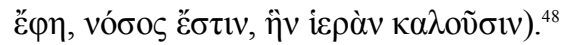

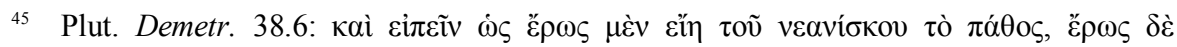

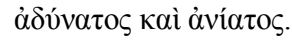

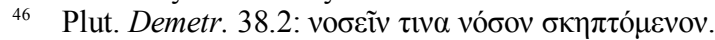

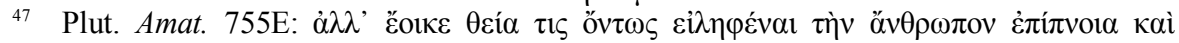

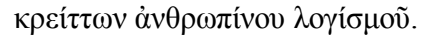

48 After comparing the lovesick Ismenadora to someone suffering from the nosos of epilepsy, the excerpt of the dialogue goes on to call this sort of erōs, the greatest and

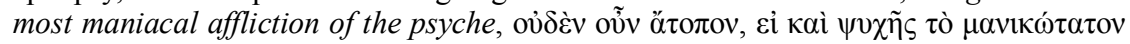

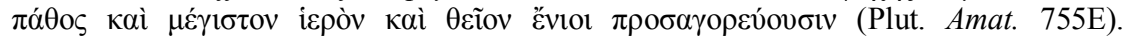




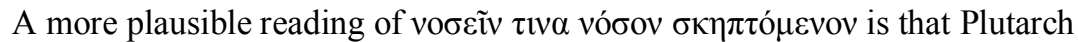
interpreted the prince to be feigning ( $\sigma \kappa \eta ் \tau \omega)$ not his condition wholesale, but the gravity of his condition by self-causing the slow consumption of his body through his refusal to eat. What seems to be in dispute is whether some of the symptoms of the royal patient were affected and self-caused. ${ }^{49}$ This reading agrees with the extent tradition in Appian that describes certain of the effects of the disease in

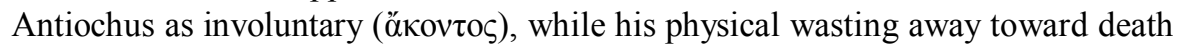

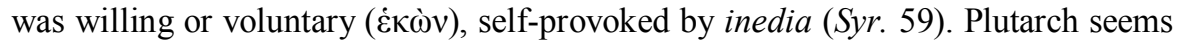
to emphasise in the passage that Antiochus was to some degree affecting or simulating $(\sigma \kappa \eta ் \pi \tau \omega)$ — in the sense of self-causing — the gravity of his condition, particularly his physical consumption. ${ }^{50}$

One reason both Appian and Plutarch define Antiochus' lovesickness as 'intractable' ${ }^{{ }^{51}}$ is because the story assumes the ancient reader's expectation that a father would not give up his own wife for his son under normal circumstances. The anecdote's prognosis of lovesickness also draws from the world of the physician and from the poetic remedia amoris tradition that to heal the sickness of erotic love

On further Plutarchan agreement with the medical tradition that saw forms of intense falling in love to be a real sickness, see also the Plutarch fragment 135, from his Пєрi

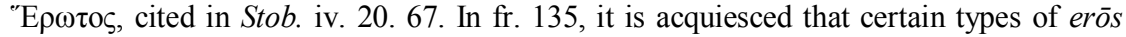
are a vóøov. The fragment interchangeably calls erōs when changed from madness to an

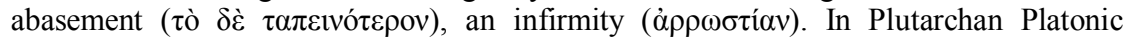
fashion, the fragment concludes by remarking that erōs, when flourishing happily, is a blessed divine inspiration and possession ( $\tau$ ò $\delta$ ' $\operatorname{vi\eta \mu \varepsilon \rho oṽv~\varepsilon ̇v\theta ov\sigma ı\alpha \sigma \mu óv).~For~fr.~135,~}$ see Sandbach 1987:252-255.

49 The trope that lovesick patients might sometimes affect or feign the gravity of their condition is developed in the romance novel tradition, such as in Apuleius, $c f$. Amundsen 1974:333.

50 Galen wrote a minor tractate on the diagnostic challenge physicians faced when patients forged a certain infirmity wholesale or feigned the gravity of their condition, De morb.

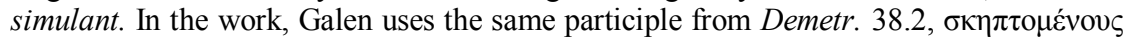
(Deichgräber \& Kudlien 1960:116), when discussing patients who exaggerate the intensity of their pain that would be otherwise not as grave. This discussion follows a medical case story of a slave who scouted on foot the roads ahead of his master's convoy. The slave complains of a terrible pain on his knee and asks to be released temporarily of his duties. Galen detects the slave was affecting (lit. adding upon) the

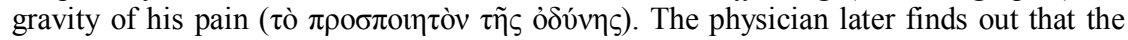
slave's swollen knee was not aching from overwork, but that the knee developed a tumor that was self-inflicted by the application of a corrosive ointment. I think that Plutarch's meaning of $\sigma \kappa \eta \pi \tau$ 'o $\mu \varepsilon v o v$ carries both senses of the scout slave's medical story. Antiochus was affecting the gravity of his condition by self-causing the worsening of his physical consumption. For Galen De morb. simulant., $c f$. Deichgräber \& Kudlien 1960:113-116.

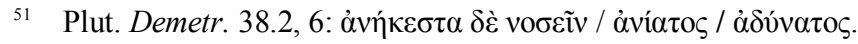


was to satisfy its demands. ${ }^{52}$ This is why the claim that king Seleucus was the one who matter of fact healed his son's illness is to be read both as eulogy and as a medical statement: Seleucus' fatherly affection for the prince allowed him to requite the prince's impossible love, healing him of his erotomania. We have seen already how the physician Caelius Aurelianus was suspicious about prescribing erōs as a remedy for erōs. But this is precisely the prescription suggested in a medical case story of a male patient suffering from depressive lovesickness recorded in the Pneumatic physician Aretaeus of Cappadocia (first century CE). Aretaeus has the male patient healed of his depressive erotomania through acquiescing to his love: "when he proclaimed the love to the girl, he ceased from his dejection, and dispelled his passion and sorrow; and with joy he sobered up from his depressive state, and he became restored to understanding, love being his physician' (On chronic diseases 1.5$).^{53}$

The treatment of requiting the demands of an ailing infatuation in the very embrace of the beloved, competed with a certain psycho-therapy, promoted for instance in Cicero, which advised the patient to replace the disease-causing love with a brand new love, 'like one nail is knocked from its hole by another' (Tusc. 4.75). It also rivalled with Epicurean love therapy, which counselled replacing obsessive erōs with enjoying the pleasures of Venus in casual sexual encounters (Rer. Nat. 4.1065-72).

It seems that at least some of these treatments of healing love with love presuppose one common remedy: sex. Among the physicians, the earliest unambiguous evidence of the recommendation of therapeutic sex to treat melancholics and the depressive lovesick is found in Rufus of Ephesus (ca. 100 $\mathrm{CE}$ ). The prescription is preserved in Sustenance of the traveller, by the Muslim doctor Ibn Al-Jazzār (d. 979) who practiced in Tunisia, and in the Medieval physician Constantine the African (d. 1087), in his Viaticum and On melancholy. ${ }^{54}$

52 Ciavolella 1976:24 speaks of this convention influencing ideas on lovesickness into medieval times.

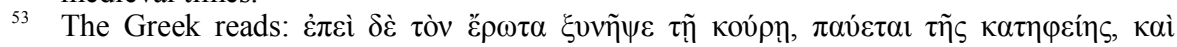

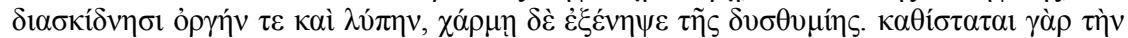
$\gamma v \omega ́ \mu \eta v$ ह̌ $\rho \omega \tau \iota ~ i \eta \eta \rho \tilde{\omega} . '$ Translation is modified from Adams 1856. The medical case history is told in 1.5 in the context of the physician's discussion of humoral melancholy. I read Aretaeus here not as disputing that his patient had a real sickness. What is in dispute is that the young man was suffering from melancholy caused by black bile. Aretaeus says that the patient only 'appeared to the common people to be melancholic

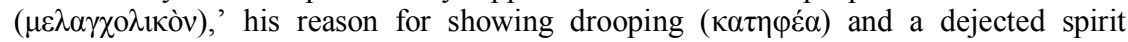

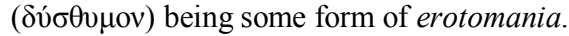

54 For an introduction to the historical relevance of the Arabic medical manual Sustenance of the traveller for the tradition on melancholic lovesickness, which is also among our most important sources on Rufus of Ephesus' On melancholy, see Wack 1990:31-35. 
The available evidence from Rufus in Constantine's Greek translation of Ibn AlJazzār asserts that sex could dissolve the preoccupations of the excessive lover, even if the patient were to have intercourse with someone other than their love object. Rufus of Ephesus' prescription of therapeutic coitus also suggests the treatment worked through regulating the imbalance in the humor of the black bile. Aretaeus' remarks (On chronic diseases 1.5) that 'erōs had been the physician'

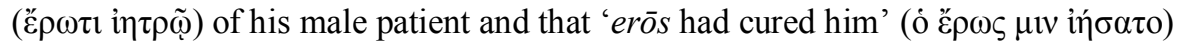
could imply also a subscription to therapeutic coitus as a course of therapy. The idea recurs in the physician of Julian the apostate, Oribasius, who recommended that melancholic symptoms would go away with therapeutic intercourse (Synopsis ad Eustathium 8). ${ }^{55}$ The Erasistratus anecdote indicates agreement with this medical advice.

Plutarch's therapeutics of lovesickness in Demetr. 38 should also be read in tandem with the philosopher's views on moral progress. Here, as in his Moralia, the ethical and therapeutic dimensions of care of the emotions are inseparable. Plutarch advocated for a therapy of the emotions the Academic-Peripatetics labelled $\sigma 0 \mu \mu \varepsilon \tau \rho i ́ \alpha \pi \alpha \theta \tilde{\omega} v$, or maintaining the 'due proportion of the passions' ${ }^{56}$ Plutarch would have seen obsessive love as both unhealthy and an impediment to moral improvement. It is in this vein that Plutarch's aetiology of lovesickness in Demetr. 38 follows Platonic soul-theory. Excessive erotomania is caused by an unbalanced distribution of power between the faculties of reason and unreason. Antiochus' lovesickness is described as a 'submission of his faculty of reason'

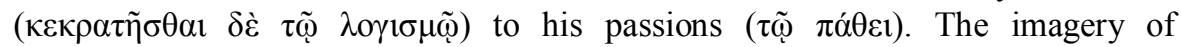
submission derives from the world of wrestling and from politics. The prince's

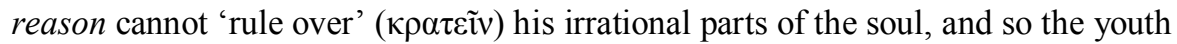
is unable to wrestle and subject ( $\delta 1 \alpha \mu \alpha ́ \chi \varepsilon \sigma \theta \alpha l)$ his passions. ${ }^{57}$ Plutarch's use of

55 Rufus of Ephesus on therapeutic coitus cited in Ibn Al-Jazzār and Constantine's On melancholy are available and translated in Pormann 2008:61 (F58 and F59, respectively). For Aretaeus of Cappadocia, cf. On chronic diseases 1.5, in Hude 1958:41. For a discussion of therapeutic sex in Oribasius and Caelius Aurelianus, see Wack 1990:10, 11-12.

56 Plutarch subscribed to the Academic-Peripatetic metriopatheia therapeutic approach to the emotions. Emotions, e.g. erōs, should be experienced in their moderate spectrum (e.g. Virt. Mor. 443 C-D), cf. Wright 2008:140-141. On Plutarch and care of the emotions see also Becchi 2012:43-53.

57 Both sets of images belong to Plato's tripartite soul-theory. See Galen, Plat. Tim. 2.1718, which describes the Platonic struggle between the rational and irrational parts of the

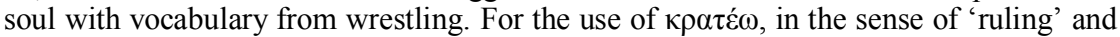
'being ruled' in Plato's soul theory, Rep. 439C and especially Rep. 440A. In Rep. 440A we see the use of both sets of imageries, whereas a soul's reason is ruled over by the 
Platonic soul-theory adds a moral philosophical aetiology to the prince's sickness: lovesickness is born out of the unruliness of the prince's seat of desire in the soul ( $\delta \varepsilon เ v \tilde{\omega} \nu \mu \dot{\varepsilon} v \dot{\varepsilon} \pi \imath v u \mu \varepsilon \tilde{v})$ and the subjugation of his reason to his emotions.

Finally, Plutarch's exposition of Antiochus' lovesickness is invested in the debate of which psychosomatic symptoms helped diagnose the disease. Demetr. 38 subscribes to the ancient medical common sense that there was a pulsus amatorius indicative of erotomania, which was marked by an irregular and violent throb

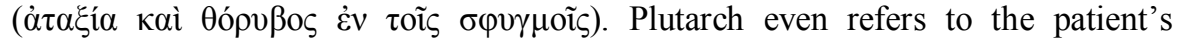
$\sigma \varphi v \gamma \mu$ ós, or natural pulse, a technical term from ancient medical manuals on sphygmology.

According to Demetr. 38, the following psychosomatic symptoms would have given away that Antiochus was suffering from lovesickness: 'Stammering voice', 'burning flushes on the skin', 'deficiency of the eyes', 'sharp sweating' and 'paleness'. Some of these symptoms are drawn from the lyrical archive and Demetr. 38 is explicit about its debt to one of the most notable depictions of the lovesick from erotic poetry, Sappho's $f r$. 31. Sappho's famed tableau describes the sick with erōs to exhibit 'a broken tongue' (trouble to speak), darkened vision, humming ears, episodes of cold sweat, trembling, a complexion of a green pallor, and lastly, as lyrical language meets ancient science, Sappho's sick lover is known for their racing heartbeat. ${ }^{58}$

Notably, some of the symptoms in the text were also known symptoms of melancholy. Besides the depressive psychological symptoms of torpor, despondency and self-harm, the lovesick Antiochus' complexion turns pale and his speech suffers from some kind of stutter. ${ }^{59}$ Medical literature on the melancholic recognized both of these as indications of a melancholia by an imbalance of the black bile. ${ }^{60}$ Medieval medical literature later singled out problems of speech as

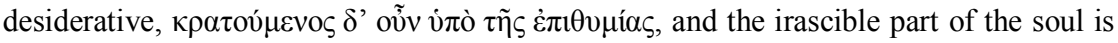
said to come to the aid of reason sometimes to fight ( $\pi \mathrm{o} \lambda \varepsilon \mu \varepsilon \tilde{i} v)$ the desires.

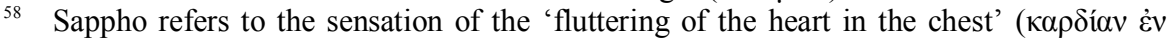

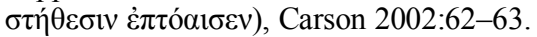

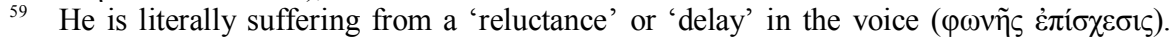
It is difficult to ascertain which ancient speech pathology is being addressed. Stuttering is a reasonable rendering. The medical terminology for stuttering is usually referred as i $\sigma \chi v o \varphi \omega v i ́ \eta$ or $\psi \varepsilon \lambda \lambda$ ó$\eta \varsigma$ in the Hippocratics and the Problemata. On ancient speech pathologies, Webster 2016:166-199.

60 Aretaeus, On chronic diseases 1.5, describes black bile melancholics as having a greenish complexion. The Hippocratics, the Problemata and Rufus all remark that black bile melancholy affected speech pathologies. In the Hippocratics, cf. Epid. 2.5.1,

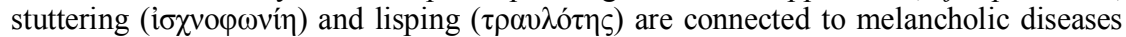
( $\mu \varepsilon \lambda \alpha \gamma \chi 0 \lambda \mathrm{\imath} \alpha \dot{\alpha}$ voбท́ $\mu \alpha \tau \alpha$ ); see also Epid. 2.6.1. In the Problemata, see [Pr.] 903B20-25

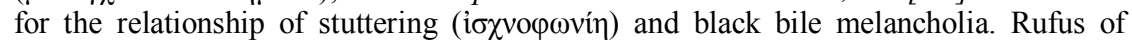


typical afflictions of erotomania. Lovesickness robbed suffering patients from the adult world of discourse and speech. ${ }^{61}$

\section{Conclusion}

Scholarship has been hesitant to take the claims of ancient physicians and philosophers who participated in the remedia amoris as a matter of fact. Stories of famed doctors who diagnose and treat patients of lovesickness are a case in point. This study has argued that the anecdotes about Hippocrates-Perdiccas in Soranus' Life of Hippocrates and about Erasistratus-Antiochus in Appian and Plutarch reflect actual medical debates on the aetiology, prognosis, diagnosis and treatment of lovesickness. In these, Hippocrates and Erasistratus of Ceos are summoned as court physicians to treat despondent royal patients with a real disease that is revealed to be erotomania, a psychosomatic depressive condition rooted in unrequited and impossible love. Against the growing popularity of humoral medicine, Soranus, Appian and Plutarch seem to dissent from the view that an imbalance in black bile explained depressive lovesickness. Rather, they treat the disease as psychic in nature, even if they do not agree on how soul and body interact and affect one another to afflict the latter. Appian apparently works with a Physicalist view of the soul, whereas Plutarch follows the Platonic tripartite soultheory of a conflict between the rational and irrational parts of the soul.

This study has also pointed out that ancient doctors were weary of misdiagnosis of lovesickness because they observed that the condition shared symptoms with humoral melancholia. The Erasistratus-Antiochus anecdote could arguably be read as engaging in a medical debate on the symptomatology of the lovesick to provide physicians with a lore to avoid such misdiagnosis. Plutarch's Demetr. 38 understands that no single symptom served as a diagnostic master-key for erotomania. For instance, against the view that a characteristic lovesick pulse (the pulsus amatorius) unlocked the diagnosis, Demetr. 38 suggests that a proper diagnosis depended on the observation of an ensemble of symptoms. The importance of the pulsus amatorius in the Erasistratus-Antiochus cycle rests more on being a tool to identify the object of the obsessive-love of the patient than as fool proof sign of erotomania. Knowing who was culpable for the patient's heartbreak, or to use of Sappho's imagery, to make the heart behave as if to 'fly off the chest' like a flock of birds, was instrumental for the tradition's best course of therapy.

Ephesus diagnosed the melancholic with speech impediments: they lisped or spoke too fast, $c f$. al-Razi, Comprehensive Book= Pormann 2008:F14.

61 Wack 1990:64. 
Returning full circle to the lyrics of Bad Medicine by Bon Jovi that opened this study: in Appian and Plutarch, knowing who was the cause of the lovesick patient's racing pulse allowed physicians to prescribe them that 'bad medicine' doctors like Rufus of Ephesus and Aretaeus thought could heal sickly erōs. To treat lovesickness, some doctors prescribed some form of requiting the love, a treatment by inoculation, so to speak. The idea behind this prescription was that erōs itself, though gone bad, could serve as its own remedy.

\section{BIBLIOGRAPHY}

Adams, F (ed.) 1856. The extant works of Aretaeus, the Cappadocian. London: Sydenham Society.

Amundsen, D W 1974. Romanticizing the ancient medical profession: The characterization of the physician in the Greco-Roman novel. Bulletin of the History of Medicine 48.3.328-37.

Becchi, F 2012. The doctrine of the passions: Plutarch, Posidonius and Galen. In Lanzillotta, L R \& Gallarte, I M (eds.), Plutarch in the religious and philosophical discourse of Late Antiquity, 43-53, Leiden: Brill.

Berrey, M 2014. The Hippocratics on male erotic desire. Arethusa 47.3:287-301.

Berrios, G E \& Kennedy, N 2002. Erotomania: A conceptual history. History of Psychiatry 13.381-400.

Breebaart, A B 1967. King Seleucus I, Antiochus, and Stratonice. Mnemosyne 20.2:154-164.

Carson, A (ed.) 2002. If not winter: Fragments of Sappho. New York: Vintage.

Ciavolella, M 1976. La 'Malattia d'amore' dall'antichità al medioevo. Roma: Bulzoni Editore.

Caston, R R 2006. Love as illness: Poets and philosophers on romantic love. CJ 101.3:271-298.

De Lacy, P 1988. The third part of the soul. In Manuli, P \& Vegetti, M (eds.), Le opere psicologiche di Galeno: Atto del Terzo Colloquio Galenico Internazionale Pavia, 10-12 Settembre 1986, 43-63. Naples: Bibliopolis.

De Lacy, P (ed.) 2005. De placitis Hippocratis et Platonis. $3^{\text {rd }}$ ed. (CGM V 4,1,2). Berlin: Akademie-Verlag.

Deichgräber, K \& Kudlien, F (ed.) 1960. Die als sogenannte Simulantenschrift griechisch überlieferten Stücke des 2. Kommentars zu Epidemien II. (CMG V 10,2,4). Berlin.

Drabkin, I E (ed.) 1950. Caelius Aurelianus. On acute diseases and on chronic diseases. Chicago: University of Chicago Press.

Durling, R J 1995. Medicine in Plutarch's 'Moralia'. Traditio 50:311-314. 
Faraone, C 1999. Ancient Greek love magic. Cambridge, Mass.: Harvard University Press.

Fraser, P M 1969. The career of Erasistratus of Ceos. Rendiconti del Istituto Lombardo 103 (Classe di Lettere e Scienze Morali e Storiche), 518-37.

Garofalo, I (ed.) 1988. Erasistrati Fragmenta. (Biblioteca di Studi Antichi 62). Pisa: Giardini Editori.

Gourevitch, D 1995. Women who suffer from a man's disease: The example of Satyriasis and the debate on affections specific to the sexes. In Howley, R \& Levick, B (eds.), Women in antiquity: New assessments, 149-165. London: Routledge.

Hett, W S (ed.) 1970. Aristotle. Problems I-II: Books I-XXXVIII. London: Heinemann.

Horine, E F 1941. An epitome of ancient pulse lore. Bulletin of the History of Medicine 10.2:209-249.

Hude, C (ed.) 1958. Aretaeus. (CMG II). Berlin.

Ilberg, J (ed.) 1927. Sorani gynaeciorum libri IV, De signis fracturarum, De fasciis, Vita Hippocratis secundum Soranum. (CMG IV). Leipzig \& Berlin: Teubner.

Jackson, S W 1986. Melancholia and depression: From Hippocratic times to modern times. Yale: Yale University Press.

Jouanna, J 2012. At the roots of melancholy: Is Greek medicine melancholic? In Van der Eijk, P (ed.), The Greek medicine from Hippocrates to Galen: Selected papers, 229-258. Leiden: Brill.

Klibansky, R et al 1979. Saturn and melancholy: Studies in the history of natural philosophy, religion and art. Nendeln: Kraus-Thomson.

Lampe G W H (ed.) 1961-1968. A Patristic Greek lexicon. Oxford: Clarendon.

Lewis, O 2016. The practical application of ancient pulse-lore and its influence on the patient-doctor interaction. In Petridou, G \& Thumiger, C (eds.), Homo patiens: Approaches to the patient in the ancient world, 345-364. Leiden: Brill.

Lloyd, G E R 1975. A note on Erasistratus of Ceos. JHS 95:172-175. 2009. Galen's un-Hippocratic case-histories. In Gill, C et al. (eds.), Galen and the world of knowledge, 115-131. Cambridge: Cambridge University Press.

Martin, D B 1997. Paul without passion: On Paul's rejection of desire and sex in marriage. In Moxnes, H (ed.), Constructing early Christian families: Family as a social reality and metaphor, 201-215. New York: Routledge.

Martin, D B 1995. The Corinthian body. New Haven: Yale University Press.

Mazzini, I 2012, Malattia melancolica da amore tra poesia e medicina nel tardo antico: Aegritudo Perdiccae (Ae.P.), Medicina nei Secoli Arte e Scienza 24. 3:559-584. 
McNamara, L 2016. Hippocratic and non-Hippocratic approaches to lovesickness. In Dean-Jones, L \& Rosen, R (eds.), Ancient concepts of the Hippocratics. (Papers presented at the XIIIth International Hippocrates Colloquium, Austin, Texas, August 2008), 308-327. Leiden: Brill.

Mesulan, M M \& Perry, J 1972. The diagnosis of love-sickness: Experimental psychopathology without a polygraph. Psychophysiology 9.5:546-551.

Minar Jr., E L et al. (ed.) 1961. Plutarch's Moralia. Vol. 9: The dialogue on love. London \& Cambridge: Heinemann \& Harvard University Press.

Nutton, V (ed.) 1979. Galen. On prognosis: Edition, translation, and commentary. (CMG V 8.1). Berlin: Akademie-Verlag.

2006. Euryphon of Cnidus. Brill's New Pauly. Online available: http://dx.doi.org.ez.sun.ac.za/10.1163/1574-9347_bnp_e406620 [27 December 2019].

2013. Ancient medicine. $2^{\text {nd }}$ ed. London: Routledge.

Perrin, B (ed.) 1959. Plutarch's Lives. Vol. 9: Demetrius and Antony, Pyrrhus and Caius Marius. London \& Cambridge: Heinemann \& Harvard University Press.

Pfaff, F (ed.) 1956. Galeni In Hippocratis epidemiarum librum VI Commentaria VI-VIII. (CMG V 10,2,2). Berlin.

Pinault, J R 1992. Hippocratic lives and legends. Leiden: Brill.

Pormann, P E (ed.) 2008. On melancholy: Rufus of Ephesus. Tubingen: Mohr Siebeck.

Robiano, P 2003. Maladie d'amour et diagnostic medical: Érasistrate, Galien et Héliodore d'Emèse, ou du récit au roman. Ancient Narrative 3:129-149.

Rosen, R M 2013. Galen, Plato and the physiology of Erôs, In Sanders, E et al. (eds.), Erôs in ancient Greece, 111-128. Oxford: Oxford University Press.

Sandbach, F H (ed.) 1987. Plutarch's Moralia. Vol. 15: Fragments. London \& Cambridge: Heinemann \& Harvard University Press.

Temkin, O (ed.) 1991. Soranus' gynecology. Baltimore: John Hopkins University Press.

Thumiger, C 2013. Mad Erôs and eroticized madness in tragedy. In Sanders, E et al. (eds.), Erôs in ancient Greece, 27-40. Oxford: Oxford University Press. 2018a. Liebe als Krankheit. Eine Geschichte von Leib und Seele in griechischer und römischer Literatur und Medizin. In Reggiani, N \& Bertonazzi, F (eds.), Parlare la medicina: fra lingue e culture, nello spazio e nel tempo. Atti del Convegno Internazionale, Università di Parma, 5-7 Settembre 2016, 253-273. Firenze: Le Monnier Università.

2018b. 'A most acute, disgusting and indecent disease': Satyriasis and sexual disorders in ancient medicine. In Thumiger, C \& Singer, P N (eds.), Mental 
illness in ancient medicine: From Celsus to Paul of Aegina, 269-284. Leiden: Brill.

Toohey, P 1990. Some ancient histories of literary melancholia. ICS 15.1:143-161. 1992. Love, lovesickness and melancholia. ICS 17.2:265-286.

2004. Melancholy, love and time: Boundaries of the self in ancient literature. Ann Arbor: The University of Michigan Press.

Tsoucalas, G et al. 2014. The pioneer physician Euryphon and his method for the determination of the female infertility in ancient Greece. Journal of Obstetrics and Gynaecology 34:369.

Van der Eijk, P 1990. Aristoteles über die Melancholie. Mnemosyne 43:33-72. 2008. Rufus' On melancholy and its philosophical background. In Pormann, P (ed.), On melancholy: Rufus of Ephesus, 159-178. Tubingen: Mohr Siebeck.

Von Staden, H 2000. Body, soul, and nerves: Epicurus, Herophilus, Erasistratus, the Stoics, and Galen. In Wright, J P \& Potter, P (eds.), Psyche and soma: Physicians and metaphysicians on the mind-body problem from antiquity to Enlightenment, 79-116. Oxford: Clarendon Press.

Wack, M F 1990. Lovesickness in the Middle Ages: The Viaticum and its commentaries. Philadelphia: University of Pennsylvania Press.

Webster, C 2016. Voice pathologies and the 'Hippocratic Triangle'. In Petridou, G $\&$ Thumiger, $\mathrm{C}$ (eds.), Homo patiens: Approaches to the patient in the ancient world, 166-199. Leiden: Brill.

Wellmann, M 1900. Zur Geschichte der Medicin im Altertum. Hermes 35.2:349384.

1907. S.v. Erasistratos. $R E, 333-350$.

1930. Beiträge zur Geschichte der Medicin im Altertum. Hermes 65.3:322331.

White, H (ed.) 1912. Appian's Roman history. Volume II. London: Heinemann.

Wright, R A 2008. Plutarch on moral progress. In Fitzgerald, J T (ed.), Passions and moral progress in Greco-Roman thought, 136-150. New York: Routledge.

Zadorojnyi, A V 1999. Sappho and Plato in Plutarch, Demetrius 38. In Perez Jiminez, A et al. (eds.), Plutarco, Platón y Aristóteles, Actas del V Congreso Internacional de la I.P.S., 515-532. Madrid: Ediciones Clásicas. 